\title{
The Impact of Intellectual Capital on the Development of Efficient Accounting Information Systems Applied In the Contributing Jordanian Industrial Companies - Viewpoint of Jordanian Accountant Auditors
}

\author{
Prof. Sulaiman Mustafa Al-Dalahmeh \\ Jerash University, Jordan \\ Email: dr.el-dalahmeh97@live.com
}

Associate Prof. Usama Abdilmune'm

Jerash University, Jordan

Email: Al_Osama@yahoo.com

Prof. Khalil Ebrahim Al-Dulaimi (Corresponding author)

Irbid National University, Jordan

Email: dr.khaldulemi@yahoo.com

Assistant Prof. Jamal Al-Afif
Jerash University, Jordan

Email: alafeefjamal@yahoo.com

Received: November 11, 2016 Accepted: November 27, 2016 Published: January 02, 2017

doi:10.5296/ijafr.v6i2.10295 URL: http://dx.doi.org/10.5296/ijafr.v6i2.10295

\begin{abstract}
The field of knowledge - based economy is known by its own excrement of the importance of intellectual systems of accounting information and leading technology communications, the accounting information systems witnessed great development as a result of the rapid development and growth in the information technology, and was accompanied by a broad and growing awareness of the importance of these systems and their substantial role in the
\end{abstract}




\section{Mll Macrothink}

International Journal of Accounting and Financial Reporting

ISSN 2162-3082

2016, Vol. 6, No. 2

success of companies on the local and global levels, as information is a valuable resource in the companies and a vital source of their strength and effectiveness, so those companies need an intellectual and leading resource to increase the efficiency of information and develop their accounting systems, and this cannot be achieved until the intellectual capital is developed, so the purpose of this study is to state the importance of the development of intellectual capital in increasing the efficiency of the applicable accounting information systems in industrial companies. The most important findings of the study are that the efficiency of accounting information systems of any accompany is measured by the benefits gained as a result of the use of the accounting system outputs compared to the costs that are sacrificed for the construction and design of the accounting system to run it as well as having an urgent need for the development of intellectual capital to enhance the efficiency of the company where accounting information systems are applied, so we will need to activate the entrepreneurial mechanism and attract industry and preserve this important resource in any company. While the study found the need for attention to the development of intellectual capital in industrial companies and made it one of the concerns of the upper Administration because of its pioneering impact on the company's business, As a growing long - term investment which is important for the owner's companies. With the need to steer the Industrial companies to the development of a clear and transparent policy to attract and stimulate the efficient elements intellectually to raise the level and quality of their IT accounting systems.

Keywords: Intellectual capital, Efficient accounting information system, Industrial linkages

\section{Introduction}

The huge cognitive revolution in technology happened whether in the domain of communication or information technology in addition to other qualitative developments which took place since the early 1990s of the last century. Leading business companies appeared and directed their investments to the development of mankind and their ideas and creativity in order to add improvements which allow competition and control. Those companies, through their creative individuals get large benefits as we see in the companies that deal in communication and smart devices. All this indicate the presence of a kind of capital which is far more important than material capital namely the intellectual capital (AlShukrji, 2010). Therefore, this study aimed at identifying the impact of intellectual capital on the development of efficient accounting information systems applied in the contributing Jordanian industrial companies.

\subsection{Objectives of the Study}

The main objectives of the study are represented in the following:

- Presenting a theoretical framework about the concept of the intellectual capital and its different developmental dimensions.

- Showing the effect of development dimensions of the intellectual capital on the 


\section{Macrothink \\ International Journal of Accounting and Financial Reporting

efficiency of the accounting information systems.

\subsection{The Importance of the Study}

The importance of the study is embodied in the following:

- The attempt to produce a comprehensive outlook about the concept of intellectual capital and the mechanisms of developing this significant resource for the industrial companies.

- Producing a brief about the impact of developing the intellectual capital on the efficiency of the accounting systems applied in the Jordanian industrial companies.

\subsection{The Problem and Questions of the Study}

The problem of the study lies in identifying the impact of intellectual capital development on the efficiency of the accounting information systems applied in the Jordanian industrial companies.

The problem of the study is represented in the following questions.

First question: In there a positive linear correlation between the polarization of the intellectual capital on the efficiency of the accounting information systems applied in the Jordanian industrial companies.

Second question: Is there a positive linear correlation between intellectual capital industry on the efficiency of accounting information systems applied in the Jordanian industrial companies.

Third question: Is there a positive linear correlation between activating the intellectual capital on the efficiency of the accounting information systems applied in the Jordanian industrial companies.

Fourth question: Is there a positive linear correlation between maintaining the intellectual capital on the efficiency of the accounting information systems applied in the Jordanian industrial companies.

The study's hypotheses: Based on the questions of the study's problem, the following hypotheses can be produced:

First hypothesis: There is no positive linear correlation between polarizing the intellectual capital on the efficiency of the accounting information systems applied in the Jordanian industrial companies.

Second hypothesis: There is no positive linear correlation between the industry of the intellectual capital on the efficiency of the accounting information systems applied in the Jordanian industrial companies.

Third hypothesis: There is no positive linear correlation between activating the intellectual capital on the efficiency of the accounting information systems applied in the Jordanian industrial companies. 


\section{Macrothink}

International Journal of Accounting and Financial Reporting

ISSN 2162-3082 2016, Vol. 6, No. 2

Fourth hypothesis: There is no positive linear correlation between maintaining the intellectual capital on the efficiency of the accounting information systems applied in the Jordanian industrial companies.

\subsection{Methodology of the Study}

The analytical descriptive approach will be adopted. The researchers will collect the needed data for this study from the following sources:

1- Primary sources.

2- Secondary sources.

\subsubsection{Primary sources}

The primary data of this study was collected through questionnaire which will be prepared and distributed on a group of external auditors who form the sample of this study then the data will be analyzed using (SPSS) to test the correctness of the study's hypotheses.

\subsubsection{Secondary sources}

The secondary data related to this study was attained by referring to books, university theses, scientific researches, and articles in journals and magazines to build the theoretical framework of the study and to achieve its objectives.

\subsubsection{Population of the Study}

The population of the study consists of the Jordanian contributing industrial companies which count 75 companies listed in Amman stock market.

\subsubsection{Sample of the study}

75 external auditors described with high skills and professional efficiency who audit the accounts of the Jordanian contributing industrial companies were collected.

\section{Previous Studies}

The study of (Abul - Ghanam, 2012)

The effect of intellectual capital development in the effectiveness of strategic information systems in the food industry companies in Jeddah.

This study aimed at identifying the effect of intellectual capital development in the effectiveness of strategic information systems in the food industry companies in Jeddah. To achieve the goals of the study, a questionnaire was developed to collect data and 104 questionnaires were distributed on the members of the study sample which consisted of the supervisory job workers in the food industry companies which counted 7 companies. The retrieved questionnaires valid for analysis were 82 questionnaires. SPSS. V. 16 was used to analyze data. The study produced a number of results:

1- The conceptions of the researched individuals at the food industry companies concerning the levels of the intellectual capital development and the managers' 


\section{Ml Macrothink}

International Journal of Accounting and Financial Reporting ISSN 2162-3082 2016, Vol. 6, No. 2

effectiveness was low 2. The presence of an effect of the intellectual capital development dimensions (intellectual capital industry, activating the intellectual capital, maintaining the intellectual capital, caring for customers) in the effectiveness of the strategic information systems in food industry companies in Jeddah. The study recommended the researched managements' attention to be directed to the necessity of connecting the policies of attracting the human resources with the efficiency standards through special service systems in those companies and the necessity of maintaining the intellectual capital through clarifying the rights, duties and development opportunities. It also recommended directing the attention of researchers to conduct similar studies in other industrial sectors, and studies related to the development of intellectual capital, institutional performance and competitive ability.

The study of Zayed (2013) under the title: The impact of accounting information systems properties on the quality of the internal auditor's performance (applied study on the Jordanian insurance companies).

This study aimed at identifying the accounting information systems effect on the internal auditor's performance through an applied study on the Jordanian insurance companies. To achieve this goal, the researcher dealt with two types of data which are the secondary data and the primary data. A questionnaire was distributed on a sample of (47) internal auditors who work at Jordanian insurance companies. The data was treated using (SPSS). The study was conducted during the period between June 2012 and January 2013. The study indicated the existence of an influence of the properties of accounting information systems (clarity and accuracy, speed and easiness, appropriation and flexibility) on the quality of the internal auditor's performance in terms of adherence to the special internal auditing standards and also in terms of the commitment to the performance standards in the Jordanian insurance companies incorporated in Amman stock market. In the light of these results, some recommendations were produced: The continuation of the feature of accuracy and clarity as they work on improving the quality of the internal auditor's performance, through improving the ability of the accounting information system to give clear information to the data users. In addition, to assert the importance of speed and easiness for the Jordanian insurance companies as an important feature of the accounting information system because of its effect in improving the quality of the internal auditor's performance.

The study of Akour (2014) with the title: The effect of accounting information systems' effectiveness on the operational and financial performance of the general contributing industrial companies in Jordan.

This study investigates the effectiveness of the accounting information systems used in the general contributing industrial companies in Jordan by showing the availability of effectiveness dimensions and their effect on the operational and financial performance of the company. The study followed the descriptive and applied approach to realize the objectives of the study. The study population consisted of all the general contributing industrial companies in Jordan. A sample of 42 industrial companies listed in Amman stock market till the end of 2012 was collected. The companies were from all the industrial sectors. The study revealed 


\section{Mll Macrothink}

International Journal of Accounting and Financial Reporting

ISSN 2162-3082

2016, Vol. 6, No. 2

that the level of the accounting information systems used in the industrial companies was high. All the effectiveness dimensions appeared in medium levels except for the dimensions of (meeting the requirements of planning and the appropriation with the organizational structure) which showed high levels. The study revealed an incorporeal impact of the accounting information systems dimensions on the operational and financial performance. The dimensions of (the internal control requirements and the fulfillment of the planning requirements) had the most significant effect on the operational performance while the most prominent impact in the financial performance was attributed to (meeting the internal control requirements, speed and easiness of attaining information and the fulfillment of performance evaluation requirements). The results of accounting information systems' effectiveness effect test on the operational performance indicators showed an unmaterial effect on each of the rate of assets turnover and the rate of the working capital turnover and the rate of the stock turnover while there was no unmaterial effect on the rate of deliberation. There was also an unmaterial effect of the efficiency of the accounting information systems on the financial performance indicators concerning the revenue of the assets and the return on property rights, while there was unmaterial effect on the profit margin and the profitability of the equity. There were no unmaterial differences in the effect of efficiency on the assets revenue and equities profitability as indicators of the financial performance due to the difference in the size of the company. The most important recommendations of the study were the necessity of developing the accounting information systems constantly to increase the susceptibility of the system to respond to the changes in the external environment to contribute in decision making, and the necessity to study and analyze the information provided by the accounting information systems in the evaluation of performance to improve the operational and financial performance.

The study of Okab, 2013 with the title "The importance of Professional specialty of External auditor in Accounting Information Systems for providing Auditing Services in Information Technology Environment - A field Study in the Jordanian Banks" This study aimed at identifying the role and importance of professional specialty in the field of information technology when providing auditing services and at determining the awareness of the auditor to the concept and benefits of professional specialty in information technology. In addition, the study aims at analyzing the importance of professional specialty in the light of information technology for the auditor especially under the increasing use of information technology in different sectors. It also aims at the importance of professional specialty for the auditor in information technology to improve the level of professional performance quality related to the auditing services presented in the banking sector. To achieve the goals of the study, the researchers studied the Jordanian banks community listed in Amman stock market counting (15) banks. A sample of external auditors of those banks were chosen through distributing (45) questionnaires. The study pointed out that the external auditor largely understands the concept of professional specialty in information technology and it realizes high level of benefits to the Jordanian banks that wish to improve the level of auditing services provided to the Jordanian banks. The study recommended that the Jordanian banks have to establish an auditing division specialized in information technology plus creating training courses to qualify employees. The study also recommended to add accounting 


\section{MlMacrothink}

International Journal of Accounting and Financial Reporting

ISSN 2162-3082

2016, Vol. 6, No. 2

information systems as a modern contemporary subject to the university subjects due to their importance in the working market.

The study of Oima \& otieno polo, 2013 with the title "Effect of Computerized accounting Systems on Audit Management in Public Enterprises: A Case of Kisumu County, Kenya"

This study aimed at verifying the impact of computerized accounting systems on audit risk management at the Kenyan enterprises. The study indicated that the continuous development in information technology led to an increasing effect on the accounting information systems. To achieve the objectives of the study, (41) questionnaires were distributed including the staff, production department and financial managers. The study also aimed at determining the relationship between the computerized accounting systems and audit risk management. It also aimed at conducting assessment procedures about risk management among the studied enterprises (the study sample) as the study considered that risk management should enhance the performance management through facilitating the efficiency of the internal control and the operational targets while it found that the risk management failed in different cases in the companies under study due to the weakness of the institutional governance. The study showed the presence of an effect or relationship between accounting information systems and audit risk management in addition to the existence of a connection between the accounting systems and their role in activating audit control and the assessment of risk management.

\section{The Theoretical Aspect}

Currently, companies which wish to be at the lead and get the largest profits and market shares are obliged to concentrate on continuous creativity and new ideas through depending on modern accounting systems and skill the available skills, creativity and knowledge which are desired by customers more than focusing on the financial investments to develop those systems. This means that those companies have to look for the suitable intellectual mechanism to develop the intellectual capital of their creative skills to maximize the efficiency of their accounting systems to reach at intellectual pioneering on the local and international level. (Samara \& Abdul Jabbar, 2013). However, we have to know the meaning of intellectual capital and its developmental dimensions and their impact on the efficiency of the accounting information systems applied in different companies.

\section{Intellectual Capital}

Intellectual capital is a relatively modern concept. Many accounting and administrative studies started to give it great attention by explaining its meaning and specifying its value and divisions, but still, many companies lack clear vision about it and about the main idea round which it revolves especially in the developing countries. We shall offer some concepts concerning intellectual capital as we see that the International Federation of Accountants (IFAC, 1998) considers the intellectual capital as a term used with the intellectual property and cognitive intellectual assets. It can also be seen as the total stock of the capital or the rights which are constructed on cognition and owned by the company. It also represents the ultimate outcome of the knowledge trans formation or knowledge itself which turns into the property or the intellectual assets of the company. The organization for Economic 


\section{Macrothink}

International Journal of Accounting and Financial Reporting

ISSN 2162-3082

2016, Vol. 6, No. 2

Cooperation and Development (OECD.1999) defined intellectual capital as the economic value of two categories of the intangible assets of the company which are the organizational capital and the human capital. The Chartered Institute of Management Accountants in Canada (CIMA, 2013) defined intellectual capital as "items based on knowledge which are owned by the company, and will result in future benefits, and include the technological and innovative abilities and administrative and consulting experiences". (Shaban, 2011, p 39) defined it as "The distinctive cognitive abilities the workers of the company have and which the company employs through its policies, programs and regulations to put them in force to present excellent services and products to customers". (Navarro et al., 2011) said that intellectual capital contains the unmaterial resources that carry a value connected to the employee's abilities plus the resources of organizations and manner of operations and relations process with stakeholders. The American society for Training and Development (ATIS) sees that the components of intellectual capital are four to reach at the intellectual pioneering (Al-Mfarji \& Saleh, 2003, 90-92):

1- Human capital which is the human cadre and its competencies and skills.

2- Creativity capital which is the ability of creativity, new production and new services.

3- Operations capital which consists of the organization's operations techniques and information systems in addition to the technical and administrative expenditure.

4- Customers' capital includes the customary relations and providing support to customers as well as marketing efficiency and ability.

This division can be expressed as follows:

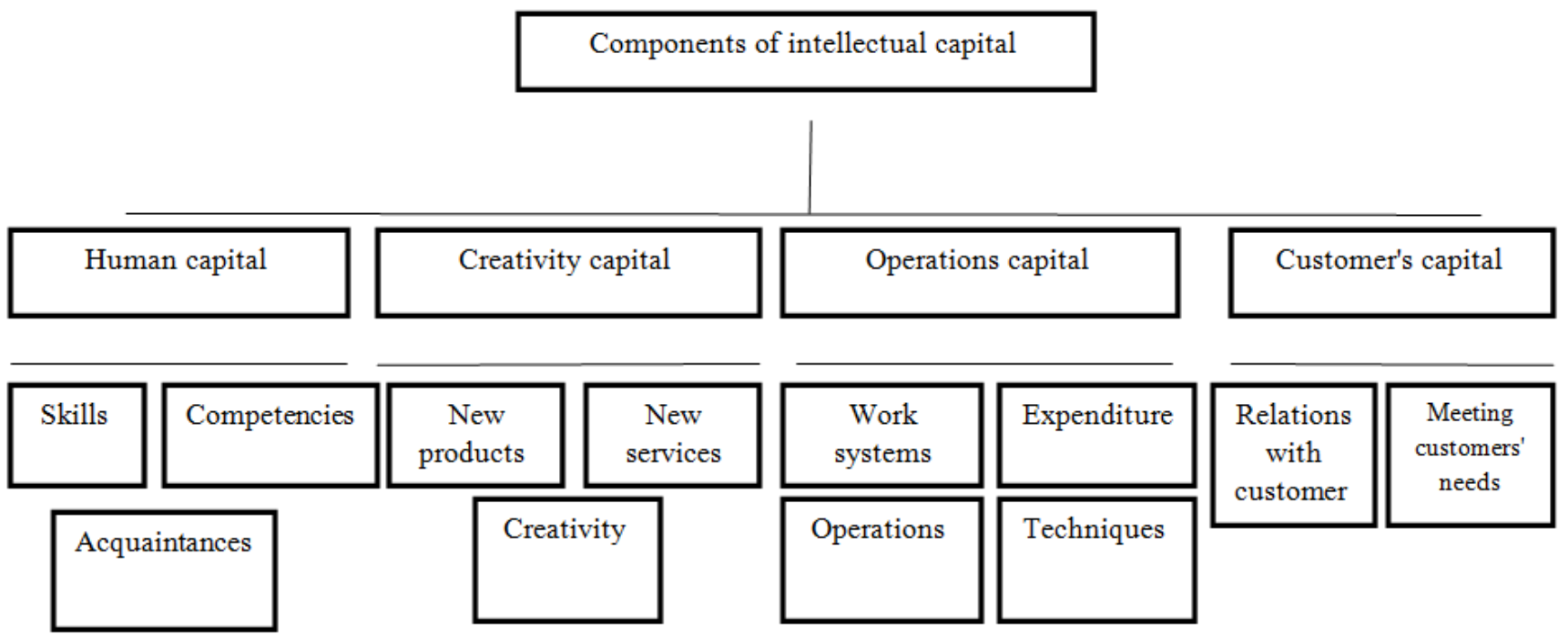

Figure (1): intellectual capital components according to the American Society for Training and Development (source: cited from Almfarji \& Saleh, 2003, 92)

Researchers agree with (Al-Dalahmeh, 2008 P 257) that the accounting information systems 


\section{Al Macrothink}

International Journal of Accounting and Financial Reporting

ISSN 2162-3082

2016, Vol. 6, No. 2

at any company are measured by the acquired benefits from using the accounting system's outputs compared with the sacrificed costs to build, design and operate the accounting system. When analyzing efficiency, the attention is focused on how to achieve the objectives with the least costs while attention is focused, when analyzing efficiency, on the realization of targets. Therefore, researchers believe that this cannot be realized unless they get a pioneering resource which is represented in the intellectual capital and the mechanism to develop it. Researchers also believe that there is an urgent need to develop the intellectual capital of any company to enhance the efficiency of the applied accounting information systems. Therefore, we need:

1- Polarization of intellectual capital: (Abulghanam, 2012) This dimension reflects the effort exerted by companies in searching and investigating high abilities and skills, in addition to providing the proper climate to attract experienced and competent people (attractive environment for competencies) through providing their economic and social needs in a way that meets their desires.

2- Intellectual capital industry:

This dimension represents the policies and practices of the companies to establish their own intellectual capital through following a number of methodological procedures like training programs and courses and social relations development programs for the members of the same company which helps to create special cognitive texture as a competitive privilege,

3- Activating intellectual capital:

Having the knowledge is not enough for the company to form a competitive advantage with strategic nature able to grow and adapt with the environmental changes unless this knowledge is activated and put into flexible executive position to be able to maintain the smooth flow of knowledge among the organizational levels of the different offices in accordance with the rearrangements and changes in the internal and external work environment.

4- Maintaining the intellectual capital:

It is the overall administrative policies and procedures taken by companies to preserve their cognitive stock of skills, experiences and knowledge within several methods and means like training, motivating, organizational learning and developing the social relations among the members of the organization in the one company. After explaining the meaning of intellectual capital and its pioneering components and their effect on the efficiency of the accounting information systems in companies, we come to state the views of the Jordanian auditors in the development of intellectual capital and its effect on the efficiency of the accounting information systems applied in the Jordanian contributing industrial companies. 


\section{The Practical Aspect}

Here is a detailed description to the demographic features of the study sample's members, as indicated in table No. (1):

\begin{tabular}{|c|c|c|c|c|}
\hline Sr. & Variables & capacity & frequency & Percentage \\
\hline \multirow{4}{*}{1} & \multirow{4}{*}{ Academic degree } & Bachelor's degree & 51 & $68 \%$ \\
\hline & & Master degree & 22 & $29.3 \%$ \\
\hline & & Ph. D & 2 & $2.7 \%$ \\
\hline & & Total & 75 & $100 \%$ \\
\hline \multirow{5}{*}{2} & \multirow{5}{*}{ Specialty } & Accounting & 45 & $60 \%$ \\
\hline & & Business administration & 20 & $26.6 \%$ \\
\hline & & Economy & 3 & $4 \%$ \\
\hline & & $\begin{array}{l}\text { Financial and banking } \\
\text { sciences }\end{array}$ & 7 & $9.4 \%$ \\
\hline & & Total & 75 & $100 \%$ \\
\hline \multirow{5}{*}{3} & \multirow{5}{*}{$\begin{array}{l}\text { Professional } \\
\text { certificate }\end{array}$} & $\mathrm{JCPA}$ & 54 & $72 \%$ \\
\hline & & ACPA & 14 & $18.7 \%$ \\
\hline & & $\mathrm{CA}$ & 4 & $5.3 \%$ \\
\hline & & APA & 3 & $4 \%$ \\
\hline & & Total & 75 & $100 \%$ \\
\hline \multirow{3}{*}{4} & \multirow[b]{3}{*}{ Years of experience } & Less than 5 years & 3 & $4 \%$ \\
\hline & & $5-10$ & 12 & $16 \%$ \\
\hline & & $10-15$ & 21 & $28 \%$ \\
\hline
\end{tabular}




\begin{tabular}{|l|l|l|l|l|}
\hline & $15-20$ & 31 & $41.3 \%$ \\
\cline { 3 - 5 } & $20+$ & 8 & $10.7 \%$ \\
\cline { 2 - 5 } & Total & 75 & $100 \%$ \\
\hline
\end{tabular}

The previous table shows that the highest percentage of the sample members have a bachelor's degree at the rate of \%68 and this indicates that the sample members have the education and knowledge related to the study's subject and this points out the validity of their answers to the questionnaire's questions putting into consideration that the sample members were specialized in accounting at the rate of $\% 60$. It is clear from the table that the largest part of the sample have JCPA at the rate of $\% 72$ which means that they have the competence of accounting and auditing work especially in the field of accounting information systems which fits with their experience which ranges between 15-20 years with the rate of $\% 41$.

\section{First: Polarizing intellectual capital}

The arithmetic means and standard deviations in polarizing intellectual capital were calculated as shown in table (2).

Table (2): The arithmetic means and standard deviations in polarizing intellectual capital in descending order

\begin{tabular}{|c|c|c|c|c|c|c|}
\hline No. & Clause & $\begin{array}{l}\text { Arithmetic } \\
\text { mean }\end{array}$ & $\begin{array}{l}\text { Standard } \\
\text { deviation }\end{array}$ & Materiality & Level & Rank \\
\hline 4 & $\begin{array}{l}\text { Industrial companies determine the level of } \\
\text { the required knowledge and information } \\
\text { skill to work in them to ensure the industrial } \\
\text { work quality and the efficiency of their } \\
\text { accounting systems. }\end{array}$ & 2.87 & 1.16 & 57.40 & average & 1 \\
\hline 2 & $\begin{array}{l}\text { The industrial companies polarize the } \\
\text { distinctive workers who have distinguished } \\
\text { informative knowledge in their industrial } \\
\text { work to raise the efficiency of their } \\
\text { accounting systems. }\end{array}$ & 2.70 & 1.00 & 54.00 & average & 2 \\
\hline 3 & $\begin{array}{l}\text { Industrial companies have clear and } \\
\text { distinctive intellectual mechanism in } \\
\text { looking for the distinguished human } \\
\text { competencies to ensure the quality of } \\
\text { industrial work and increase the efficiency }\end{array}$ & 2.70 & 0.91 & 54.00 & average & 2 \\
\hline
\end{tabular}




\section{Macrothink}

International Journal of Accounting and Financial Reporting ISSN 2162-3082 2016, Vol. 6, No. 2

\begin{tabular}{|l|l|l|l|l|l|l|}
\hline & of their accounting systems. & & & & & \\
\hline 1 & $\begin{array}{l}\text { Industrial companies, in their search for } \\
\text { human resources, depend on the standards } \\
\text { of competency which is expected to attain } \\
\text { from the surrounding environment of the } \\
\text { company. }\end{array}$ & 2.57 & 1.25 & 51.40 & average \\
\hline & Polarizing intellectual capital & 2.72 & 0.91 & 54.21 & average \\
\hline
\end{tabular}

Table (2) shows that the level of intellectual capital polarization was average as the arithmetic mean was (2.72) with a materiality of (54.21). The level of the domain's clauses was average, where the arithmetic means ranged between $(2.57-2.87)$. The first rank was occupied by clause (4) which states, "Industrial companies determine the level of the required knowledge and information skill to work in them to ensure the industrial work quality and the efficiency of their accounting systems" with an arithmetic mean of (2.87) and a materiality of (57.40). This indicates the belief of industrial companies in the necessity of workers to have the intellectual pioneering resource represented in the intellectual capital to ensure the quality of their industrial works and the quality of the applied accounting systems. In the last rank came clause (1) which is, "Industrial companies, in their search for human resources, depend on the standards of competency which is expected to attain from the surrounding environment of the company" with an arithmetic mean of (2.57) and a materiality of (51.40).

\section{Second: Intellectual capital industry}

The arithmetic means and standard deviations were calculated in the intellectual capital industry. Table (3) shows the results.

Table (3) the arithmetic means and standard deviations of the intellectual capital industry in descending order

\begin{tabular}{|l|l|l|l|l|l|l|}
\hline No. & Clause & $\begin{array}{l}\text { Arithmetic } \\
\text { mean }\end{array}$ & $\begin{array}{l}\text { Standard } \\
\text { deviation }\end{array}$ & Materiality & Level & Rank \\
\hline 4 & $\begin{array}{l}\text { Industrial companies participate in the } \\
\text { scientific conferences and seminars related } \\
\text { to their work to raise the efficiency of their } \\
\text { industrial performance and accounting } \\
\text { systems. }\end{array}$ & 3.13 & 1.08 & 62.60 & average & 1 \\
\hline 2 & $\begin{array}{l}\text { Industrial companies are connected with } \\
\text { other companies through mutual } \\
\text { cooperation relations to enhance the stock of } \\
\text { industrial and information knowledge of }\end{array}$ & 2.70 & 1.04 & 54.00 & average & 2 \\
\hline
\end{tabular}




\section{Macrothink}

\begin{tabular}{|c|c|c|c|c|c|c|}
\hline & their systems. & & & & & \\
\hline 3 & $\begin{array}{l}\text { Industrial companies have a specialized } \\
\text { management that cares for the development } \\
\text { and innovation of industrial knowledge } \\
\text { which affects the efficiency and strength of } \\
\text { their accounting systems. }\end{array}$ & 2.70 & 1.13 & 54.00 & average & 2 \\
\hline 5 & $\begin{array}{l}\text { Industrial companies give importance to the } \\
\text { team work systems and working in the team } \\
\text { spirit to generate pioneering industrial } \\
\text { knowledge. }\end{array}$ & 2.65 & 0.82 & 53.00 & average & 4 \\
\hline 1 & $\begin{array}{l}\text { Industrial companies depend on the } \\
\text { pioneering intellectual scientific research to } \\
\text { create new knowledge related to their } \\
\text { different industrial and information } \\
\text { activities. }\end{array}$ & 2.52 & 1.22 & 50.40 & average & 5 \\
\hline & Intellectual capital industry & 2.75 & 0.789 & 54.81 & average & \\
\hline
\end{tabular}

Table (3) indicates that the level of intellectual capital industry was average. The arithmetic mean was (2.75) with materiality of (54.81). The level of the domain's clauses was average as the arithmetic means ranged between $(2.52-3.13)$. Item (4) took the first rank stating "Industrial companies participate in the scientific conferences and seminars related to their work to raise the efficiency of their industrial performance and accounting systems" with an arithmetic mean of (3.13) and a materiality of (62.60), this shows the keenness of the Jordanian industrial companies to follow up with new ideas to develop their industrial work and information systems. In the last rank came clause(1) which is "Industrial companies depend on the pioneering intellectual scientific research to create new knowledge related to their different industrial and information activities" with an arithmetic mean of (2.52) and a materiality of (50.40).

\section{Third: Activating intellectual capital}

The arithmetic means and standard deviations in activating intellectual capital were calculated as shown in table (4). 


\section{1) Macrothink \\ International Journal of Accounting and Financial Reporting \\ ISSN 2162-3082 \\ 2016, Vol. 6, No. 2}

Table (4) the arithmetic means and standard deviations in activating intellectual capital in descendent order

\begin{tabular}{|c|c|c|c|c|c|c|}
\hline No. & Clause & $\begin{array}{l}\text { Arithmetic } \\
\text { mean }\end{array}$ & $\begin{array}{l}\text { Standard } \\
\text { deviation }\end{array}$ & Materiality & Level & Rank \\
\hline 8 & $\begin{array}{l}\text { Industrial companies use practical methods } \\
\text { to discover new ideas like brainstorming } \\
\text { and educational workshops or else to raise } \\
\text { the quality of their industrial products and } \\
\text { accounting systems. }\end{array}$ & 3.48 & 1.25 & 69.60 & average & 1 \\
\hline 3 & 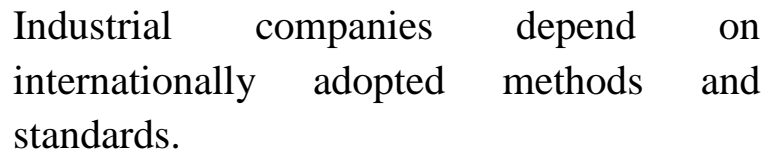 & 2.70 & 0.86 & 54.00 & average & 2 \\
\hline 1 & $\begin{array}{l}\text { Industrial companies provide policies and } \\
\text { programs that develop the creative cognitive } \\
\text { and intellectual abilities of their workers. }\end{array}$ & 2.65 & 1.01 & 53.00 & average & 3 \\
\hline 4 & $\begin{array}{l}\text { Work policies and procedures in the } \\
\text { company give the workers more freedom for } \\
\text { creativity and innovation to ensure the } \\
\text { industrial quality. }\end{array}$ & 2.57 & 0.97 & 51.40 & average & 4 \\
\hline 6 & $\begin{array}{l}\text { Industrial companies use pioneering } \\
\text { mechanism to activate their workers in a } \\
\text { pioneering intellectual approach. }\end{array}$ & 2.57 & 1.06 & 51.40 & average & 4 \\
\hline 5 & $\begin{array}{l}\text { Work duties and tasks contain a sort of } \\
\text { challenge which enhances the creativity of } \\
\text { workers. }\end{array}$ & 2.48 & 0.98 & 49.60 & average & 6 \\
\hline 7 & $\begin{array}{l}\text { Industrial companies follow developed } \\
\text { scientific and practical information methods } \\
\text { in their industrial operations. }\end{array}$ & 2.48 & 1.02 & 49.60 & average & 6 \\
\hline 2 & $\begin{array}{l}\text { Industrial companies managements discuss } \\
\text { work rules and procedures with workers } \\
\text { periodically to raise their industrial quality. }\end{array}$ & 2.43 & 0.97 & 48.60 & average & 8 \\
\hline & Activating intellectual capital & 2.68 & 0.71 & 53.41 & average & \\
\hline
\end{tabular}




\section{Macrothink}

International Journal of Accounting and Financial Reporting

ISSN 2162-3082 2016, Vol. 6, No. 2

Table (4) points out that the level of intellectual capital activation was average as the arithmetic means ranged between (2.43-3.48). The first rank was taken by clause (8) which states "Industrial companies use practical methods to discover new ideas like brainstorming and educational workshops or also to raise the quality of their industrial products and accounting systems" with an arithmetic mean of (3.48) and materiality of (69.60) and this the keenness of the Jordanian industrial companies to use modern scientific methods to elevate their industrial and information quality. In the last rank came clause (2) which is "Industrial companies managements discuss work rules and procedures with workers periodically to raise their industrial quality" with an arithmetic mean of (2.43) and materiality of (48.60).

\section{Fourth: maintaining intellectual capital}

The arithmetic means and standard deviations of maintaining intellectual capital were calculated as shown in table (5).

Table (5) the arithmetic means and standard deviations of maintaining intellectual capital in descending order.

\begin{tabular}{|c|c|c|c|c|c|c|}
\hline No. & Clause & $\begin{array}{l}\text { Arithmetic } \\
\text { mean }\end{array}$ & $\begin{array}{l}\text { Standard } \\
\text { deviation }\end{array}$ & Materiality & Level & Rank \\
\hline 4 & $\begin{array}{l}\text { Industrial companies provide chances for } \\
\text { job promotion and development for their } \\
\text { workers to ensure the industrial and } \\
\text { information quality. }\end{array}$ & 2.43 & 0.88 & 48.60 & average & 1 \\
\hline 1 & $\begin{array}{l}\text { Industrial companies provide information } \\
\text { programs and pioneering training, } \\
\text { developmental and educational activities } \\
\text { constantly to ensure their industrial quality. }\end{array}$ & 2.35 & 0.96 & 47.00 & average & 2 \\
\hline 3 & $\begin{array}{l}\text { Industrial companies support the pioneering } \\
\text { ideas and experiences presented by workers } \\
\text { and adopt them to raise the industrial and } \\
\text { information quality of their accounting } \\
\text { systems. }\end{array}$ & 2.35 & 0.76 & 47.00 & average & 2 \\
\hline 2 & $\begin{array}{l}\text { Wages and rewards in the industrial } \\
\text { companies suit the size of the workers' } \\
\text { achievements and creativity. }\end{array}$ & 2.22 & 1.07 & 44.40 & Low & 4 \\
\hline & Maintaining intellectual capital & 2.35 & 0.77 & 46.81 & average & \\
\hline
\end{tabular}

Table (5) shows that the level of maintaining intellectual capital was medium as the 


\section{Macrothink}

International Journal of Accounting and Financial Reporting

ISSN 2162-3082

2016, Vol. 6, No. 2

arithmetic mean reached at (2.35) with a materiality of (46.81). the level of the domain's clauses was between low and medium. The arithmetic means ranged between $(2.22-2.43)$ he first rank was taken by clause (4) which states "Industrial companies provide chances for job promotion and development for their workers to ensure the industrial and information quality" with an arithmetic mean of (2.43) and a materiality of (48.60) and this indicates that industrial companies follow up with pioneering and new issues to be applied in their industrial work and information systems. In the last rank came clause (2) which is "Wages and rewards in the industrial companies suit the size of the workers' achievements and creativity" with an arithmetic mean of (2.22) and a materiality of (44.40).

Fifth: The efficiency of the accounting information systems applied in the Jordanian industrial companies

Table (6): the arithmetic means and standard deviations of the efficiency of the accounting information systems applied in the Jordanian industrial companies - for the dependent variable in descending order.

\begin{tabular}{|c|c|c|c|c|c|c|}
\hline No. & Clause & $\begin{array}{l}\text { Arithmetic } \\
\text { mean }\end{array}$ & $\begin{array}{l}\text { Standard } \\
\text { deviation }\end{array}$ & Materiality & Level & Rank \\
\hline 1 & $\begin{array}{l}\text { The accounting information systems applied } \\
\text { in the company gives the ability to elevate } \\
\text { the competency and ability of workers for } \\
\text { development and progress. }\end{array}$ & 2.61 & 1.10 & 52.20 & average & 1 \\
\hline 8 & $\begin{array}{l}\text { The accounting information systems applied } \\
\text { in the company contribute in providing the } \\
\text { information that meets the needs of the } \\
\text { client from the industrial products of the } \\
\text { company. }\end{array}$ & 2.43 & 0.88 & 48.60 & average & 2 \\
\hline 4 & $\begin{array}{l}\text { The accounting information systems of the } \\
\text { company provide the information that } \\
\text { reduces errors during their industrial work } \\
\text { to raise the efficiency. }\end{array}$ & 2.39 & 1.01 & 47.80 & average & 3 \\
\hline 6 & $\begin{array}{l}\text { The accounting information systems of the } \\
\text { company can provide the required } \\
\text { information to take the appropriate decision } \\
\text { concerning the wishes and needs of the } \\
\text { client. }\end{array}$ & 2.39 & 1.01 & 47.80 & average & 3 \\
\hline 7 & $\begin{array}{l}\text { The accounting information systems of the } \\
\text { company give the ability to adapt with the }\end{array}$ & 2.30 & 0.86 & 46.00 & average & 3 \\
\hline
\end{tabular}




\section{NIInstitutemk}

International Journal of Accounting and Financial Reporting

ISSN 2162-3082

2016, Vol. 6, No. 2

\begin{tabular}{|c|c|c|c|c|c|c|}
\hline & $\begin{array}{l}\text { external environment to raise the efficiency } \\
\text { of its industrial performance. }\end{array}$ & & & & & \\
\hline 2 & $\begin{array}{l}\text { The accounting information systems of the } \\
\text { company employ modern devices and } \\
\text { programs to raise the efficiency of its } \\
\text { industrial performance. }\end{array}$ & 2.22 & 1.02 & 44.40 & Low & 6 \\
\hline 3 & $\begin{array}{l}\text { The accounting information systems of the } \\
\text { company give information about the training } \\
\text { programs to elevate the efficiency of its } \\
\text { employees. }\end{array}$ & 2.22 & 0.89 & 44.40 & Low & 7 \\
\hline 5 & $\begin{array}{l}\text { The accounting systems applied in the } \\
\text { company encourage to find the appropriate } \\
\text { environment to create the spirit of creativity } \\
\text { and innovation among its workers. }\end{array}$ & 2.22 & 0.89 & 44.40 & Low & 7 \\
\hline & $\begin{array}{l}\text { The efficiency of the accounting } \\
\text { information systems applied in the } \\
\text { Jordanian industrial companies. }\end{array}$ & 2.38 & 0.64 & 47.41 & average & \\
\hline
\end{tabular}

Table (6) shows the efficiency of accounting information systems applied in the Jordanian industrial companies for the dependent variable as the arithmetic mean was (2.38) with a materiality of (47.41). The level of the domain's clauses ranged between low and average as the arithmetic means ranged between $(2.22-2.61)$. En the first rank came clause (1) which is "The accounting information systems applied in the company gives the ability to elevate the competency and ability of workers for development and progress" with an arithmetic mean of (2.61) and materiality of (52.20) this indicates the importance of having developed systems for their ability to create effective change, not only in the efficiency and ability of the workers but also on the company as a whole. The last rank was taken by clauses (3) and (5) which are "The accounting information systems of the company give information about the training programs to elevate the efficiency of its employees" and "The accounting systems applied in the company encourage to find the appropriate environment to create the spirit of creativity and innovation among its workers" with an arithmetic mean of (2.22) and a materiality of (44.40).

\section{Testing Hypotheses}

\subsection{First Hypothesis}

There is no positive linear correlation between polarizing the intellectual capital on the efficiency of the accounting information systems applied in the Jordanian industrial companies. 


\section{Macrothink}

International Journal of Accounting and Financial Reporting

ISSN 2162-3082

2016, Vol. 6, No. 2

The simple regression analysis was used to test this hypothesis and the following table shows the results of the test.

Table (7) the results of the simple linear regression analysis to investigate the relationship between intellectual capital polarizations on the efficiency of the accounting information systems applied in the Jordanian industrial companies

\begin{tabular}{|l|l|l|l|l|l|l|l|l|}
\hline Independent variable & $\mathrm{R}$ & $\mathrm{R}^{2}$ & $\mathrm{f}$ & $\operatorname{Sig} \mathrm{f}$ & $\beta_{0}$ & $\beta$ & $\mathrm{t}$ & Sig $\mathrm{t}$ \\
\hline $\begin{array}{l}\text { Intellectual capital } \\
\text { polarization }\end{array}$ & 0.439 & 0.192 & 26.89 & 0.000 & 1.548 & 0.303 & 5.18 & $* 0.000$ \\
\hline
\end{tabular}

* refers to the presence of statistically significant relationship

The results reveals a statistically significant relationship between the intellectual capital polarization on the efficiency of the accounting information systems applied in the Jordanian industrial companies as the value of the relationship between the two variables reached at (0.439) which is considered statistically significant because the calculated $\mathrm{f}$ value which is (26.89) was statistically significant at (0.000) which is less than 0.05 and the value of coefficient $\beta$ shows the effect of the independent variable on the value of the dependent variable (The efficiency of the accounting information systems applied in the Jordanian industrial companies) in the regression model which was achieved as the value of this effect was $(0.303)$. The value of $t$ shows the linear significance of the coefficient $(\beta)$. Since the values of the significance level $(0.000)$ of the intellectual capital polarization variable was less than 0.05 , the value of the coefficient has its significance in the regression model. The values of $\mathrm{R}^{2}$ refer to the variance rate of the dependent variable which can be explained through the independent variable and this rate was (\%19.2) which indicates the ability of the independent variable to predict the dependent variable. With this result, the null hypothesis of the study is rejected while the alternative was accepted i.e. there is a positive linear correlation between intellectual capital polarization on the efficiency of the accounting information systems applied in the Jordanian industrial companies.

\subsection{Second Hypothesis}

There is no positive linear correlation between the industry of the intellectual capital on the efficiency of the accounting information systems applied in the Jordanian industrial companies.

The simple regression analysis was used to test this hypothesis and the following table shows the results of the test.

Table (8) the results of the simple linear regression analysis to investigating the relationship between intellectual capital industry on the efficiency of the accounting information systems applied in the Jordanian industrial companies. 


\begin{tabular}{|l|l|l|l|l|l|l|l|l|}
\hline Independent variable & $\mathrm{R}$ & $\mathrm{R}^{2}$ & $\mathrm{f}$ & $\mathrm{Sig} \mathrm{f}$ & $\beta_{0}$ & $\beta$ & $\mathrm{t}$ & $\mathrm{Sig} \mathrm{t}$ \\
\hline $\begin{array}{l}\text { Intellectual } \\
\text { industry }\end{array}$ & 0.602 & 0.361 & 63.88 & 0.000 & 1.061 & 0.478 & 7.99 & $* 0.000$ \\
\hline
\end{tabular}

*refers to the presence of statistically significant relationship

The results reveals a statistically significant relationship between the Intellectual capital industry on the efficiency of the accounting information systems applied in the Jordanian industrial companies as the value of the relationship between the two variables reached at (0.602) which is considered statistically significant because the calculated $\mathrm{f}$ value which is (63.88) was statistically significant at $(0.000)$ which is less than 0.05 and the value of coefficient $\beta$ shows the effect of the independent variable on the value of the dependent variable (The efficiency of the accounting information systems applied in the Jordanian industrial companies) in the regression model which was achieved as the value of this effect was $(0.478)$. The value of $t$ shows the linear significance of the coefficient $(\beta)$. Since the values of the significance level (0.000) of the Intellectual capital industry variable was less than 0.05 , the value of the coefficient has its significance in the regression model. The values of $\mathrm{R}^{2}$ refer to the variance rate of the dependent variable which can be explained through the independent variable and this rate was (\%36.1) which indicates the ability of the independent variable to predict the dependent variable. With this result, the null hypothesis of the study is rejected while the alternative was accepted i.e. there is a positive linear correlation between Intellectual capital industry on the efficiency of the accounting information systems applied in the Jordanian industrial companies.

\subsection{Third Hypothesis}

There is no positive linear correlation between activating the intellectual capital on the efficiency of the accounting information systems applied in the Jordanian industrial companies.

The simple regression analysis was used to test this hypothesis and the following table shows the results of the test.

Table (9) the results of the simple linear regression analysis to investigating the relationship between intellectual capital activation on the efficiency of the accounting information systems applied in the Jordanian industrial companies. 
MInstitute ${ }^{\text {Mach }}$

\begin{tabular}{|l|l|l|l|l|l|l|l|l|}
\hline Independent variable & $\mathrm{R}$ & $\mathrm{R}^{2}$ & $\mathrm{f}$ & Sig f & $\beta_{0}$ & $\beta$ & $\mathrm{t}$ & Sig t \\
\hline $\begin{array}{l}\text { Intellectual capital } \\
\text { activation }\end{array}$ & 0.577 & 0.331 & 55.99 & 0.000 & 0.999 & 0.513 & 7.48 & $* 0.000$ \\
\hline
\end{tabular}

* refers to the presence of statistically significant relationship

The results reveals a statistically significant relationship between Intellectual capital activation on the efficiency of the accounting information systems applied in the Jordanian industrial companies as the value of the relationship between the two variables reached at (0.557) which is considered statistically significant because the calculated $\mathrm{f}$ value which is (55.99) was statistically significant at (0.000) which is less than 0.05 and the value of coefficient $\beta$ shows the effect of the independent variable on the value of the dependent variable (The efficiency of the accounting information systems applied in the Jordanian industrial companies) in the regression model which was achieved as the value of this effect was $(0.513)$. The value of $t$ shows the linear significance of the coefficient $(\beta)$. Since the values of the significance level $(0.000)$ of the Intellectual capital activation variable was less than 0.05 , the value of the coefficient has its significance in the regression model. The values of $\mathrm{R}^{2}$ refer to the variance rate of the dependent variable which can be explained through the independent variable and this rate was (\%33.1) which indicates the ability of the independent variable to predict the dependent variable. With this result, the null hypothesis of the study is rejected while the alternative was accepted i.e. there is a positive linear correlation between Intellectual capital activation on the efficiency of the accounting information systems applied in the Jordanian industrial companies.

\subsection{Fourth Hypothesis}

There is no positive linear correlation between maintaining the intellectual capital on the efficiency of the accounting information systems applied in the Jordanian industrial companies.

Table (10) the results of the simple linear regression analysis to investigating the relationship between maintaining intellectual capital on the efficiency of the accounting information systems applied in the Jordanian industrial companies.

\begin{tabular}{|l|l|l|l|l|l|l|l|l|}
\hline Independent variable & $\mathrm{R}$ & $\mathrm{R}^{2}$ & $\mathrm{f}$ & $\mathrm{Sig} \mathrm{f}$ & $\beta_{0}$ & $\beta$ & $\mathrm{t}$ & $\operatorname{Sig} \mathrm{t}$ \\
\hline $\begin{array}{l}\text { maintaining intellectual } \\
\text { capital }\end{array}$ & 0.624 & 0.388 & 71.55 & 0.000 & 1.161 & 0.517 & 8.46 & $* 0.000$ \\
\hline
\end{tabular}

* refers to the presence of statistically significant relationship

The results reveals a statistically significant relationship between maintaining intellectual capital on the efficiency of the accounting information systems applied in the Jordanian 
industrial companies as the value of the relationship between the two variables reached at (0.624) which is considered statistically significant because the calculated $\mathrm{f}$ value which is (71.55) was statistically significant at (0.000) which is less than 0.05 and the value of coefficient $\beta$ shows the effect of the independent variable on the value of the dependent variable (The efficiency of the accounting information systems applied in the Jordanian industrial companies) in the regression model which was achieved as the value of this effect was (0.517). The value of $t$ shows the linear significance of the coefficient $(\beta)$. Since the values of the significance level (0.000) of maintaining intellectual capital variable was less than 0.05 , the value of the coefficient has its significance in the regression model. The values of $\mathrm{R}^{2}$ refer to the variance rate of the dependent variable which can be explained through the independent variable and this rate was (\%38.8) which indicates the ability of the independent variable to predict the dependent variable. With this result, the null hypothesis of the study is rejected while the alternative was accepted i.e. there is a positive linear correlation between maintaining intellectual capital on the efficiency of the accounting information systems applied in the Jordanian industrial companies.

\section{Results}

1- The efficiency of accounting information systems in any company is measured by the attained benefits by using the outputs of the accounting system compared with the sacrificed costs to build, design and operate the accounting system.

2- There is an urgent need for any company to develop the intellectual capital to enhance the applied accounting information systems. Therefore, we need the pioneering mechanism to activate, polarize, make and maintain this important resource at any company.

3- The industrial companies work to determine the level of knowledge and information skills to ensure the quality of their industrial work and the efficiency of their accounting systems.

4- The accounting information systems applied in the company raise the workers' efficiency and their ability to develop and achieve progress.

5- Industrial companies provide chances for job progress and development for their workers to ensure their industrial and information quality.

6- Industrial companies participate in the scientific conferences and symposiums related to the nature of their work to raise the level of their industrial performance and the efficiency of their accounting systems.

7- The industrial companies use practical means to find new ideas like brainstorming and educational workshops to raise the level of industrial products and the quality of their accounting systems.

\section{Recommendations}

1- The necessity of caring for intellectual capital development in the industrial companies 


\section{Macrothink}

International Journal of Accounting and Financial Reporting

ISSN 2162-3082

2016, Vol. 6, No. 2

as a main interest for the higher administration because of its pioneering effect on the company being a long - term growing investment for the companies.

2- Directing the industrial companies to place a clear and transparent policy to polarize and activate their competent members intellectually to elevate the level and quality of their accounting information systems.

3- The necessity for the Jordanian industrial companies managements to care for the development of intellectual capital for its effect in improving their accounting information systems through spreading an intellectual culture to enhance the importance of this great resource.

4- The necessity of stimulating the intellectual creative elements of the workers to the accounting information systems in the industrial companies due to their role to realize local and international pioneering.

\section{References}

Abul - Ghanam, khaled Mohammad, (2012), The impact of intellectual capital development in the effectiveness of the strategic information systems at the food industry companies in Jeddah, journal of management and economy, Basra University, Vol. 5 No. 9, Al-Basrah. Iraq, [10-11.

Ackour, Samer M. Hussein (2014), the effect of accounting information systems on the operational and financial performance in the Jordanian contributing industrial companies, $\mathrm{Ph}$. D theses, University of the World Islamic Sciences and Education University, Amman, Jordan.

Al-Dalahmeh, sulaiman Mustafa (2008), The basics of accounting information systems and accounting information technology, Al-Warrak est. for publishing and distribution, 1 st ed. Amman, Jordan.

Al-Mfarji, Adel and Saleh, Ahmad Ali (2003). Intellectual capital: measurement methods and means of its maintenance, Arab organization for administrative development, Cairo, Egypt.

Al-Samarah, Mohammad and Abdul-Jabbar, Usama (2013). The effect of applying the balanced performance card on intellectual capital in the Jordanian general contributing industrial companies: field study. Al-Idari journal, Oman, Oman Sultanate, P 13-14.

Al-Shkerji, Mohamoud (2010), the measurement of intellectual capital and its effect on the bank's profitability. Takreet journal for the administrative and economic sciences, Iraq. No. 20, vol. 6, p 3 .

Certified Institute of Management Accounting (CIMA),(2003). Understanding Corporate Value, Meaning, Reporting Intellectual Capital. http://www.cimaglobal.com.

Navarro, J.L.A., Ruiz, V.R.L., and Pena, D.N. (2011). Estimation of Intellectual Capital in the European Union Using a Knowledge Model. Zb. Rad. Ekon. Fak. Rij, Vol. 29, No. 1, pp. 109- 


\section{Macrothink \\ International Journal of Accounting and Financial Reporting \\ ISSN 2162-3082 \\ 2016, Vol. 6, No. 2}

132.

OECD (1999). "Measuring and Reporting Intellectual Capital: Experience, Issues and Prospect Programme. Note and Background to Technical Meeting and Policy and Strategy Forum. The Organization for Economic Co-operation and Development (OECD), Paris.

Otieno Polo. J , Dr.Oima D. ,(2013), Effect of Computerised Accounting Systems on Audit Risk Management in Public Enterprises: A Case of Kisumu County, Kenya. International Journal of Education and Research, Vol. 1 No. 5 May 2013, p.1.

Reem okab, (2013), The importance of Professional specialty of External Auditor in Accounting Information Systems for providing Auditing Services in Information Technology Environment - A field Study in the Jordanian Banks, European Journal of Business and Management, Vol.5, No.7, 2013, p.207.

Shaban, Mustafa (2011). Intellectual capital and its role to achieve competitive and vantage for the Palestinian communication company Jawwal, unpublished M.A, the Islamic university, Gazza, Palestine.

Zayed, Linah Mustafa (2013), the effect of accounting information systems' properties on the quality of the internal auditor's performance (Applied study on the Jordanian insurance companies). Master theses in accounting, Arab university of Amman, Amman, Jordan.

The International Federation of Accountants (IFAC), 1998, http://www.ifac.org

\section{Copyright Disclaimer}

Copyright for this article is retained by the author(s), with first publication rights granted to the journal.

This is an open-access article distributed under the terms and conditions of the Creative Commons Attribution license (http://creativecommons.org/licenses/by/3.0/). 